\title{
Genetic polymorphisms in key hypoxia- regulated downstream molecules and phenotypic correlation in prostate cancer
}

Avelino Fraga ${ }^{1,2,3^{*}}$, Ricardo Ribeiro ${ }^{2,4,5}$, André Coelho ${ }^{6}$, José Ramon Vizcaíno ${ }^{6}$, Helena Coutinho ${ }^{7}$, José Manuel Lopes ${ }^{7,8}$, Paulo Príncipe ${ }^{1,2}$, Carlos Lobato ${ }^{9}$, Carlos Lopes ${ }^{3}$ and Rui Medeiros ${ }^{3,4}$

\begin{abstract}
Background: In this study we sought if, in their quest to handle hypoxia, prostate tumors express target hypoxia-associated molecules and their correlation with putative functional genetic polymorphisms.

Methods: Representative areas of prostate carcinoma $(n=51)$ and of nodular prostate hyperplasia $(n=20)$ were analysed for hypoxia-inducible factor 1 alpha (HIF-1a), carbonic anhydrase IX (CAIX), lysyl oxidase (LOX) and vascular endothelial growth factor (VEGFR2) immunohistochemistry expression using a tissue microarray. DNA was isolated from peripheral blood and used to genotype functional polymorphisms at the corresponding genes (HIF1A +1772 C > T, rs11549465; CA9+ 201 A > G; rs2071676; LOX +473 G > A, rs1800449; $K D R-604 \mathrm{~T}>$ C, rs2071559).

Results: Immunohistochemistry analyses disclosed predominance of positive CAIX and VEGFR2 expression in epithelial cells of prostate carcinomas compared to nodular prostate hyperplasia $(P=0.043$ and $P=0.035$, respectively). In addition, the VEGFR2 expression score in prostate epithelial cells was higher in organ-confined and extra prostatic carcinoma compared to nodular prostate hyperplasia ( $P=0.031$ and $P=0.004$, respectively). Notably, for LOX protein the immunoreactivity score was significantly higher in organ-confined carcinomas compared to nodular prostate hyperplasia $(P=0.015)$. The genotype-phenotype analyses showed higher LOX staining intensity for carriers of the homozygous $L O X+473 \mathrm{G}$-allele $(P=0.011)$. Still, carriers of the KDR-604 Tallele were more prone to have higher VEGFR2 expression in prostate epithelial cells $(P<0.006)$.

Conclusions: Protein expression of hypoxia markers (VEGFR2, CAIX and LOX) on prostate epithelial cells was different between malignant and benign prostate disease. Two genetic polymorphisms ( $L O X+473 \mathrm{G}>\mathrm{A}$ and KDR-604 T > C) were correlated with protein level, accounting for a potential gene-environment effect in the activation of hypoxia-driven pathways in prostate carcinoma. Further research in larger series is warranted to validate present findings.
\end{abstract}

Keywords: Genetic polymorphism, Hypoxia, Hypoxia-inducible factor 1, Prostate cancer

\footnotetext{
* Correspondence: avfraga@gmail.com

${ }^{1}$ Department of Urology, Porto Hospital Centre - St. António Hospital, Largo

Prof. Abel Salazar, 4000-001 Porto, Portugal

${ }^{2}$ Center for Urological Research, Department of Urology, Porto Hospital

Centre - St. António Hospital, Porto, Portugal

Full list of author information is available at the end of the article
} 


\section{Background}

Prostate carcinoma is the most common cancer and the second cause of death due to malignancy in men [1]. It is clinically heterogeneous in aggressiveness, not with standing comparable clinicopathological features. Currently, only few biomarkers assist prostate carcinoma risk and aggressiveness prediction [2].

During tumor growth, malignant cells become progressively distant from the vasculature, oxygen supply and nutrients, urging tumor cells to signal to the microenvironment their needs. The hypoxia inducible factor 1 alpha $(\mathrm{HIF}-1 \alpha)$ is a key factor by which tumors regulate the response to hypoxia, triggering cascades with effects in angiogenesis, energy metabolism, vasomotor function and on apoptosis and proliferation activity [3-5]. In hypoxia, the HIF- $1 \alpha / \mathrm{HIF}-1 \beta$ complex binds hypoxia response elements in promoters of many downstream target genes, notably vascular endothelial growth factor $(V E G F)$, carbonic anhydrase IX (CAIX), and lysyl oxidase $(L O X)$ promoters. They have been demonstrated to be up-regulated by hypoxia, ensuing aggressive and treatment-resistant tumor phenotypes [3, 5-9]. A large randomized study on radiotherapy and surgical cohorts described that markers of tumor hypoxia and angiogenesis were relevant for localized prostate carcinoma and outcome of radical treatment [10]. However, further studies at the genetic and protein levels are required to confirm molecules in hypoxia pathway as useful markers in prostate carcinoma.

Genetic variants may predispose to prostate carcinoma and influence the clinical outcome [2, 11, 12]. Single nucleotide polymorphisms (SNPs) in genes coding for molecules involved in the response to hypoxia, particularly a functional polymorphism in $H I F 1 A$ gene at locus +1772 C > T [13-20], has been studied in association with prostate carcinoma with controversial results. Current knowledge suggests that we should consider a panel of genes in hypoxia pathway, in order to provide more accurate prediction of the response to tumor hypoxia [21, 22]. Therefore, despite functional SNPs in genes of pathways downstream of HIF-1 $\alpha$, such as $K D R$,
$L O X$ and $C A I X$, have not been studied so far in prostate carcinoma patients, they merit further research as they represent key molecules in hypoxia-generated stimulus in cancer.

Based on the role of hypoxia-associated molecules in cancer cell biological behaviour and clinical outcome, we assumed there might be an association, at the genetic and protein level, between $H I F 1 A, L O X, C A 9$ and $K D R$ genetic variants, the protein expression and prostate carcinoma. Hence, if these polymorphisms modulate protein expression in response to tumor hypoxia, then the knowledge of the genotype could aid identify patients at higher risk for prostate carcinoma and eventually more aggressive disease, thereby making it possible to undertake chemoprevention strategies adjusted to the individual characteristics of the patient.

\section{Methods}

\section{Patients}

Sixty-seven patients with prostate pathology $(n=49$ with carcinoma, and $n=18$ with nodular hyperplasia) and elective for prostatic surgery [radical prostatectomy and simple (open) prostatectomy, respectively] at the Porto Hospital Centre - Sto. António Hospital and Porto Military Hospital were included in this study. Inclusion criteria were: 45-75 years of age and for prostate carcinoma absence of previous treatments. Clinicopathological data was collected from clinical files and pathological staging was determined according to European Association of Urology guidelines [23] as organ-confined (T1-T2) (OCPCa) or extra prostatic (T3-T4) (EPCa) disease. Descriptive data is depicted on Table 1. This study was conducted with informed written consent by participants and after approval by the Porto Hospital Centre Ethical Committee.

\section{DNA extraction and genotyping}

At the time of surgery, a venous blood sample was obtained by forearm venepuncture and the white cell fraction used to extract DNA (QIAmp DNA Blood Mini

Table 1 Descriptive clinicopathological data of participating patients

\begin{tabular}{llll}
\hline & BPH & OCPCa & EPCa \\
\hline Age at diagnosis, yrs & $67.8 \pm 8.4$ & $61.3 \pm 6.4$ & $63.3 \pm 6.3$ \\
PSA at diagnosis, $\mathrm{ng} / \mathrm{mL}$ & $5.5 \pm 5.1$ & $6.6 \pm 2.4$ & $11.9 \pm 5.6$ \\
Weight of the prostate, g & $94.8 \pm 32.1$ & $45.9 \pm 14.3$ & $56.6 \pm 22.7$ \\
Gleason Score & & & $14(43.8)$ \\
$<7$ & - & $18(56.3)$ & $0(0.0)$ \\
$\geq 7$ & - & $15.0(6.3-20.0)$ & $19(100)$ \\
Percentage of tumor $^{2}, \%$ & - & $57.0(28.8-78.8)$
\end{tabular}

Continuous variables were parametric (Shapiro-Wilk) (data presented as mean \pm standard deviation) except for percentage of tumor [data shown as median (interquartile range)]. Categorical variable is depicted as number of observations and respective frequencies. $B P H$ nodular prostate hyperplasia, $E P C a$ extra prostatic cancer, OCPC $a$ organ-confined prostate carcinoma, PSA prostate specific antigen

a prostatectomy specimens 
Kit, Qiagen). Candidate SNPs were selected from the best evidence from published studies that provide information on phenotypic risks. Candidate genes involved in key hypoxia pathways were selected. Four putative functional SNPs in 4 different genes were selected $(H I F 1 A+1772$ $\mathrm{C}>\mathrm{T}$, rs11549465; CA9+201 A > G, rs2071676; LOX +473 G>A, rs1800449; KDR-604 T>C, rs2071559). These SNPs were genotyped by Real-Time PCR (TaqMan allelic discrimination) using pre-designed validated Taqman assays (Applied Biosystems). Quality control included non-template controls in all runs and blind replicate genotypes assessment in $5 \%$ of the samples.

\section{Immunohistochemistry and scoring}

Formalin-fixed paraffin embedded tissues were morphologically assessed on haematoxylin-eosin stained slides, before tissue microarray construction as previously described [24]. Representative areas of carcinoma and of nodular hyperplasia were selected and included into tissue arrays: prostate carcinoma $(n=51)$ and nodular hyperplasia $(n=20)$, to analyse HIF- $1 \alpha$, LOX, CAIX and VEGFR2 immunohistochemistry expression. Slides were stained with mouse monoclonal antibody to HIF- $1 \alpha$ (dilution 1:100, NB100-105, Novus Biologicals), and rabbit polyclonal antibodies to LOX, (dilution 1:100, ab 31238, Abcam), VEGFR2 (dilution 1:200, ab 2349, Abcam) and CAIX, (dilution 1:1000, NB100-417, Novus Biologicals) using the VENTANA BenchMark XT series slidestaining instrument (with the VENTANA ultraView DAB IHC detection kit) (VENTANA, Tucson, AZ, United States). Negative controls omitting the primary antibody confirmed specificity. Immunohistochemistry evaluation was independently reviewed by two pathologists (JRV and AC) to assess VEGFR2 expression in carcinoma vasculature and prostate epithelial cells (carcinoma and nodular hyperplasia), and HIF-1 $\alpha$, LOX and CAIX in prostate epithelial cells (carcinoma and nodular hyperplasia). Discordant cases were discussed in order to attain a final consensus. For VEGFR2 different scoring approaches were evaluated for vessels and epithelial cells as described by Holzer et al. [25], whereas analysis of CAIX, HIF- $1 \alpha$ and LOX expression in prostatic epithelial cells (both in carcinoma and nodular hyperplasia) were performed according to Smyth et al. [26], Vergis et al. [10] and Albinger-Hegyi [27], respectively. Briefly, for VEGFR the level of intensity of tumor cell staining $(0$, no staining; $1+$, weak staining; $2+$, moderate staining; $3+$, intense staining) was made in the cytoplasmic and nuclear compartments simultaneously. The value of each staining level $(0,1,2$ or 3$)$ was multiplied by the respective percentage of tumor cells at that intensity level. A total VEGFR2 $\mathrm{H}$-score represents the sum of the three scores. Regarding LOX, only cytoplasmic immunoreactivity of epithelial cells was considered positive expression, whereas staining in the stromal component was not used. The LOX immunoreactivity score (IRS), was calculated multiplicating the percentage of positive cells (scored 0 if $0 \%$ cells; 1 if $1-20 \%$ cells; 2 if $21-40 \%$ cells; 3 if $41-60 \%$ cells; 4 if $61-80 \%$; 5 if $81-100 \%$ cells) with staining intensity (with 0 if negative; 1 if weak; 2 if moderate; 3 if strong staining intensity). A representative image of the expression of each aforementioned protein is shown in Fig. 1.

\section{Statistical analysis}

We used means as descriptive statistics for continuous variables and the Shapiro-Wilk test to assess their departure from normality. As appropriate, the Mann-Whitney test and Student $t$-test were used to compare means between prostatic disease groups. The Kruskal Wallis followed by Mann-Whitney two samples tests were used for analyses of non-parametric variables. The Pearson chisquare was used to test for association between categorical variables based on the distribution among diseases, protein expression or genotype groups. Odds ratios (ORs) and $95 \%$ confidence intervals $(95 \% \mathrm{CIs}$ ) were calculated to evaluate the associations between CAIX expression with risk for developing organ-confined and extra prostatic carcinoma. When appropriate, non-parametric Spearman's correlation was computed to assess the statistical dependence between variables. Analyses were performed using SPSS 17.0. The datasets analysed during the current study are available from the corresponding author on reasonable request.

\section{Results}

Association of hypoxia proteins with prostate cancer and extra-prostatic disease

To assess the prevalence of the key hypoxia-associated proteins in prostate carcinomas and nodular prostate hyperplasia, a tissue microarray was constructed for immunohistochemistry analyses. Immunohistochemistry for cytoplasmic HIF-1 $\alpha$ demonstrated a non-significant trend $(P=0.111)$ for increased proportion of localized prostate carcinoma patients with positive malignant prostatic epithelial cells (Fig. 2). CAIX immunoreactivity was observed in the cytoplasm of epithelial cells and significant differences were found among disease groups: CAIX expression was predominantly positive in epithelial cells of carcinomas $(P=0.043)$ (Fig. 2).

Lysyl oxidase protein expression was found in prostate epithelial cells of a high percentage of cases, notably in carcinomas of patients with organ-confined malignancy (92.0\%), but no significant differences were found among pathologic groups $(P=0.266)$ (Fig. 2$)$. Nevertheless, the immunoreactivity score (IRS), which combines intensity with amount of cells positive for LOX in prostate epithelial cells, was significantly higher in organ-confined carcinomas compared to nodular prostate hyperplasia $(P=0.015)$ 

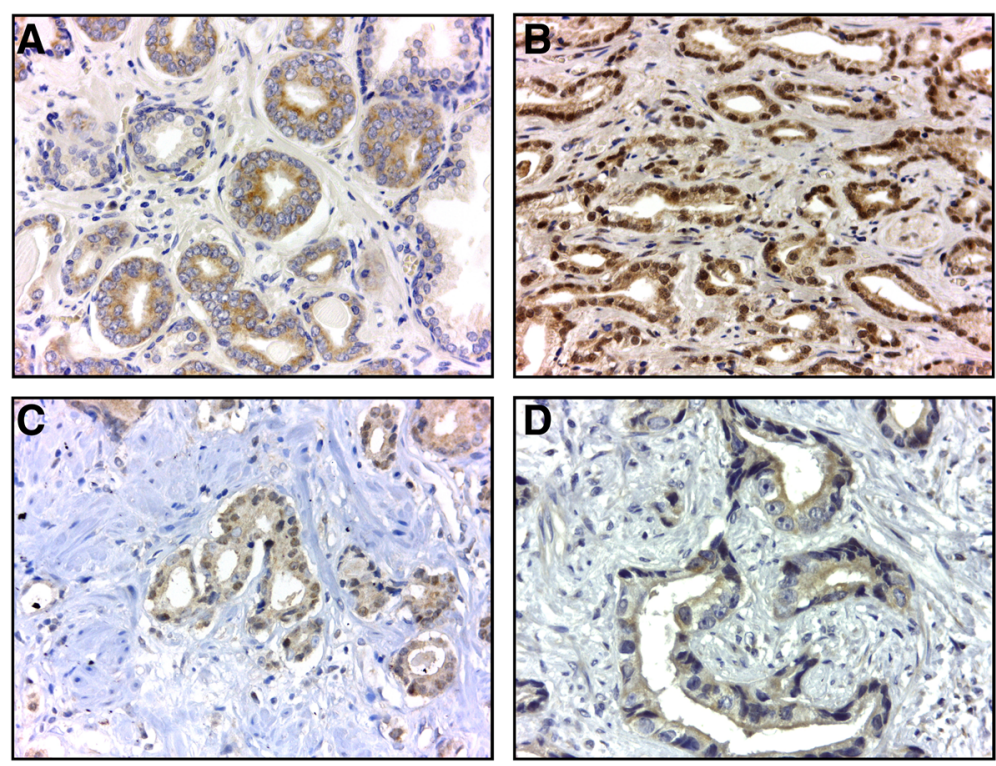

Fig. 1 Representative microscopy images of staining for hypoxia markers in prostate tissues (MO, 400X). A) HIF-1a - notice the granular cytoplasmic immunoreactivity of the malignant epithelial cells. In this case, more than 50\% of the glands stained. B) LOX - strong and diffuse nuclear immunoreactivity of the epithelial cells. C) CAIX - note a focal apical cytoplasmic immunoreactivity in epithelial cells. D) VEGFR2 - moderate nuclear and weak cytoplasmic expression of the epithelial cells
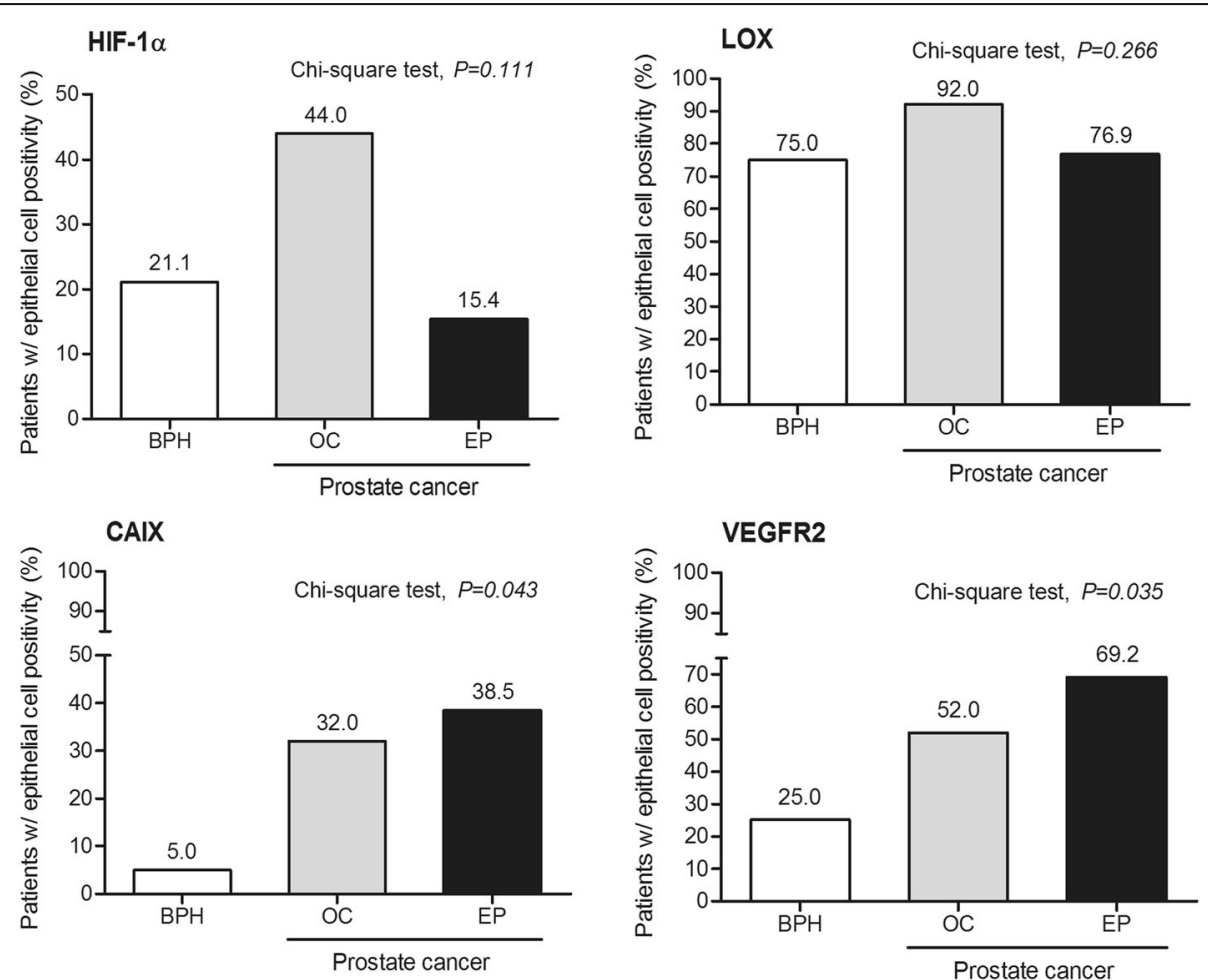

Fig. 2 Frequency of patients with positive staining in benign (BPH) and malignant (organ-confined and extra prostatic disease) epithelial cells. CAIX, carbonic anhydrase IX; HIF-1a, hypoxia inducible factor - 1 alpha; LOX, lysyl oxidase; VEGFR2, vascular endothelial growth factor receptor 2. $\mathrm{BPH}$, nodular prostate hyperplasia; EP, extra prostatic disease; OC, organ-confined disease 
(Fig. 3). Noteworthy, patients with positive HIF-1 $\alpha$ expression were more prone to have higher immunoreactivity score for LOX $(P=0.053)$ (Fig. 4). In addition, a trend exists for HIF-1 $\alpha$ immunostaining grade to be correlated with LOX IRS expression (Spearman correlation coefficient, $r^{2}=0.255, P=0.055$ ).

Cytoplasmic and nuclear VEGFR2 immunoreactivity was observed in vascular endothelial cells of approximately $20 \%$ of all samples. The difference between vascular positivity for VEGFR2 in nodular prostate hyperplasia and both organ-confined and extra prostatic carcinomas was not statistically significant $(P=0.971)$. As for VEGFR2 staining in epithelial prostate cells, almost $70 \%$ of patients with extra prostatic carcinomas and approximately half of organ-confined carcinomas showed tumor cell immunoreactivity for VEGFR2, whereas only $25 \%$ of nodular prostate hyperplasia were positive $(P=0.035)$ (Fig. 2). The VEGFR2 expression scores in the prostate epithelial cells in nodular prostate hyperplasia $(5.6 \pm 3.9)$ compare to either organ-confined $(41.6 \pm 16.5)$ or extra prostatic carcinomas $(68.7 \pm 28.4)$ were statistically different $(P=0.031$ and $P=0.004$, respectively) (Fig. 5). The VEGFR2 epithelial cell H-score for samples that were positive for VEGFR2 in the vasculature showed a trend for being higher than those with negative immunoreactivity status $(P=0.062)$, indicating a positive association between the expression of VEGFR2 in the prostatic epithelial cells and the vasculature.

\section{Genotype-phenotype correlation}

The genotypic distribution in polymorphisms HIF1A $+1772 \mathrm{C}>\mathrm{T}, L O X+473 \mathrm{G}>\mathrm{A}, C A 9+201 \mathrm{~A}>\mathrm{G}$ and $K D R$ $-604 \mathrm{~T}>\mathrm{C}$ is shown in Additional file 1: Table S1. There

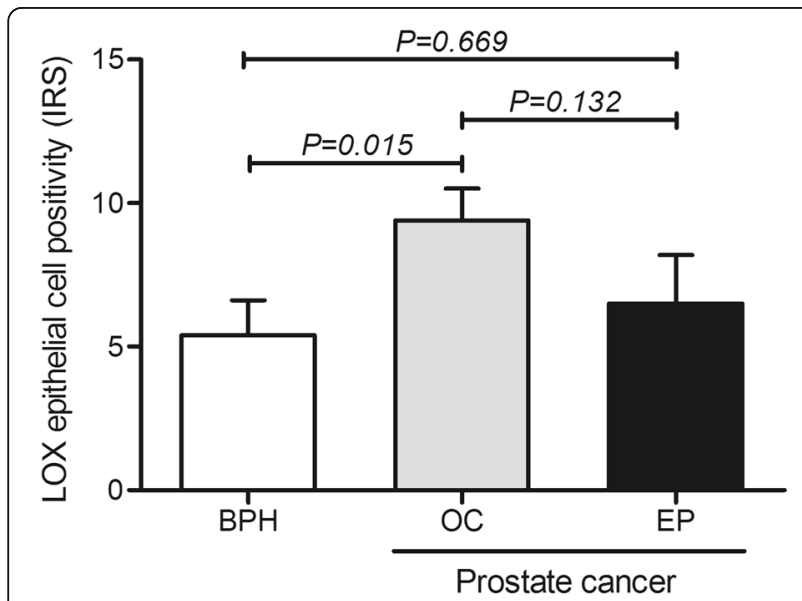

Fig. 3 Comparison of LOX immunoreactivity score in prostate epithelial cells of benign and malignant patients. BPH, nodular prostate hyperplasia; EP, extra prostatic disease; OC, organ-confined disease. LOX, lysyl oxidase; IRS, immunoreactivity score. Kruskall-Wallis followed by Mann-Whitney non-parametric tests were used to calculate differences between prostatic pathologies

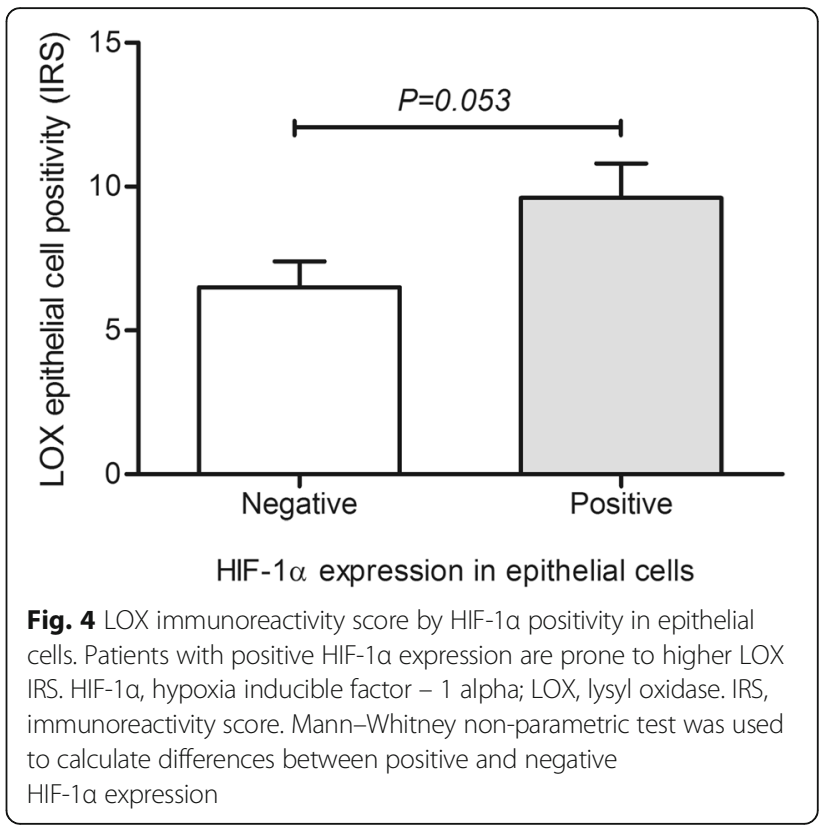

was no over-represented genotype in disease groups using either the additive or recessive models.

There was lack of association between both HIF1A $+1772 \mathrm{C}>\mathrm{T}$ and $C A 9+201 \mathrm{~A}>\mathrm{G}$ genotypes and positivity or intensity for HIF-1 $\alpha$ and CAIX protein expression (Table 2). Conversely, the LOX immunoreactivity intensity was significantly higher in individuals carrying the $L O X$ +473 homozygous $\mathrm{G}$ allele (GG, $2.0 \pm 0.2)$ compare to A carriers $(1.1 \pm 0.2)(P=0.011)$ (Fig. 6), despite no significance was achieved for IRS (but with similar trend) according to $L O X$ genotypes in recessive model. Patients

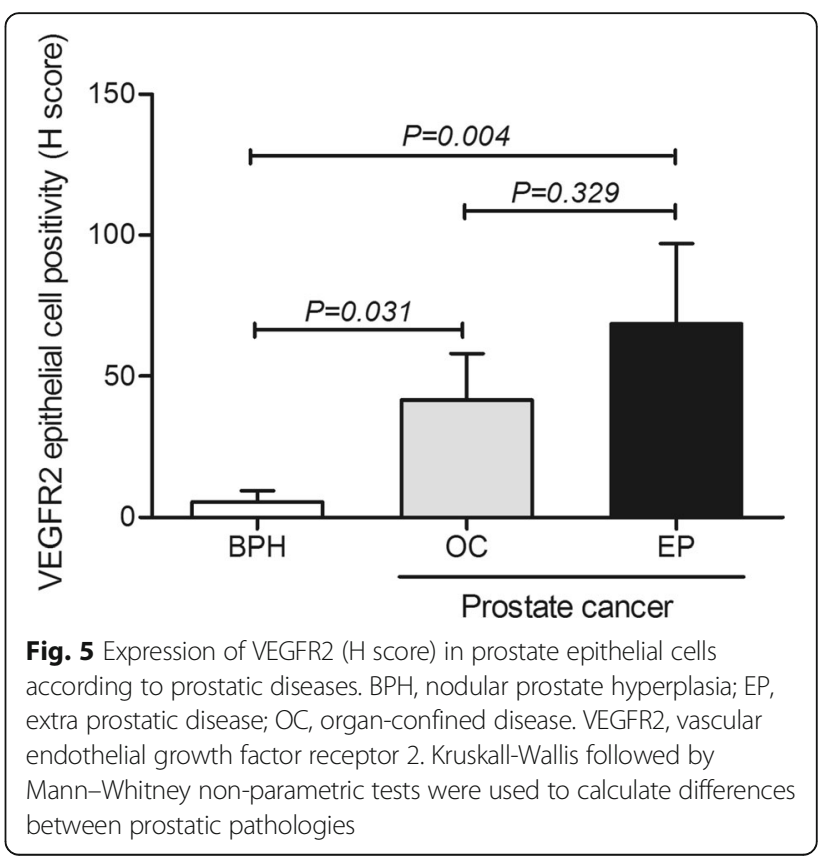


Table 2 Association of the genetic polymorphisms in HIFIA +1772 C> T and CA9+201 A > G with HIF-1a and CAIX immunoreactivity in prostatic epithelial cells

\begin{tabular}{llll}
\hline & \multicolumn{2}{l}{ Recessive model (HIF1A and CA9) } & \\
\cline { 2 - 3 } HIF-1a expression & \multicolumn{1}{l}{ CC } & TT/CT & \\
\hline Negative & $28(0.76)$ & $9(0.24)$ & 0.928 \\
Positive & $10(0.77)$ & $3(0.23)$ & \\
$<50 \%$ & $32(0.74)$ & $11(0.26)$ & \\
$\geq 50 \%$ & $6(0.86)$ & $1(0.14)$ & 0.516 \\
CAIX expression & GG & GA/AA & \\
Negative & $9(0.75)$ & $20(0.69)$ & \\
Positive & $3(0.25)$ & $9(0.31)$ & 0.699 \\
\hline a Fisher exact test & & &
\end{tabular}

with at least one $K D R-604$ T-allele were more prone to have VEGFR2 expression in prostate epithelial cells but not in vessels (Table 3). Since the presence of VEGFR2 immunoreactivity in epithelial cells, but not in vessels, was associated with the $K D R$ genetic polymorphism, we looked for its association with VEGFR2 $\mathrm{H}$-score only in prostate epithelial cells. The $\mathrm{H}$-score was significantly higher in cases carrying the T allele (CT, 38.9 \pm 13.0 and TT, $74.7 \pm 33.0)$ compare to homozygous C $(1.64 \pm 1.0)$ (Fig. 7). Both additive and recessive models show that the allele $\mathrm{T}$ was related with increased VEGFR2 epithelial cell positivity ( $P=0.017$ and $P=0.006$, respectively).

Only data from prostate carcinomas was used to evaluate if hypoxia proteins associated with Gleason score or prostate specific antigen (PSA) $>10 \mathrm{ng} / \mathrm{mL}$ (Table 4). Trends were observed for higher VEGFR2 $\mathrm{H}$-score expression in more undifferentiated carcinomas (Gleason $\geq 7)(P=0.099)$ and in patients with PSA $\geq 10 \mathrm{ng} / \mathrm{mL}(P=0.085)$, and for positive CAIX expression in prostate carcinomas from patients with PSA above $10 \mathrm{ng} / \mathrm{mL}(P=0.078)$.

\section{Discussion}

Tumor-associated hypoxia was found in over $70 \%$ of solid malignancies, including prostate carcinoma [3]. It promotes tumor progression and resistance to therapies through an effect in reducing apoptosis, and increasing tumor cell proliferation and neoangiogenesis [5]. However, the hypoxia-driven HIF- $1 \alpha$ upregulation also activates downstream pathways involved in metabolism (e.g. CAIX), angiogenesis (e.g. VEGF/VEGFR2 pathway) and extracellular matrix activity (e.g. LOX), which can modulate cancer behavior [28].

Experimental studies with prostate cancer cells demonstrated that HIF- $1 \alpha$ overexpression was associated with higher proliferation and metastatic potential [29]. Likewise, a greater expression of HIF- $1 \alpha$ has been found in human prostate carcinomas compared to nodular prostate hyperplasia [30, 31]. For prostate carcinoma and other oncologic models, besides the observed higher amount of HIF- $1 \alpha$ in tumors, increased HIF- $1 \alpha$ expression was also associated with prognosis [10, 32-35]. In the current study, we found a trend for higher HIF- $1 \alpha$ protein expression in prostate carcinomas compared to nodular prostate hyperplasia, which may be explained by the limited samples analysed. The use of cytoplasmic rather than nuclear staining, is unlikely to have influenced our results, since this method has been published before, reporting positive associations of HIF- $1 \alpha$ with prostate carcinoma and prognosis [10, 30].

Albeit mainly distributed in vascular endothelial cells, also epithelial cells express VEGFR2 that signals through signal transducer and activator of transcription 3 (STAT3), mitogen-activated protein kinase (MAPK) or phosphoinositide-3-kinase (PI3K) intracellular signalling cascades [36-38]. Unambiguously, the VEGFR2 was shown to regulate protein kinase B (Akt)/mammalian target of rapamycin (mTOR)/ribosomal protein S6 kinase beta-1 (P70S6K) signalling pathway in PC-3 prostate cancer cell line [39]. In the present study, VEGFR2 was more frequently expressed in epithelial tumor cells of organ confined or extra prostatic carcinomas than in nodular prostate hyperplasia, and to lower extent in endothelial cells. Hence, at least in prostate tissue,
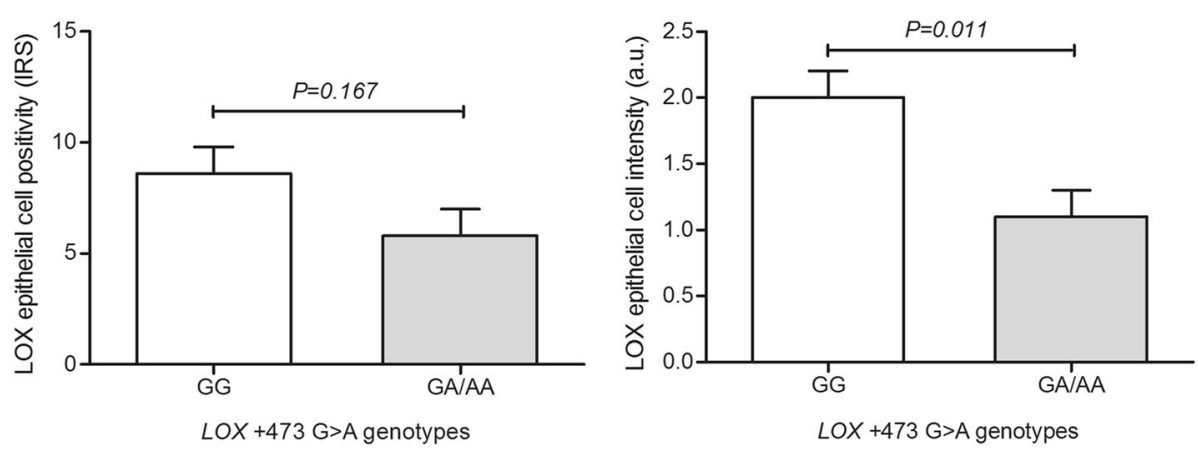

Fig. 6 LOX protein expression (both for immunoreactivity score and staining intensity) according to $L O X+473 \mathrm{G}>\mathrm{A}$ polymorphism. IRS, immunoreactivity score; LOX, lysy oxidase; a.u., arbitrary units 
Table 3 Association of the KDR-604 T > C genetic polymorphism with VEGFR2 immunoreactivity in vessels and in prostatic epithelial cells

\begin{tabular}{|c|c|c|c|c|c|c|c|}
\hline & \multicolumn{3}{|c|}{ Additive model } & \multirow[b]{2}{*}{$\mathrm{P}^{\mathrm{a}}$} & \multicolumn{2}{|c|}{ Recessive model } & \multirow[b]{2}{*}{$P^{a}$} \\
\hline & $\overline{C C}$ & CT & $\pi$ & & $\overline{C C}$ & $\pi / C T$ & \\
\hline \multicolumn{8}{|c|}{ Vessels VEGFR+ } \\
\hline Negative & $11(0.26)$ & $22(0.53)$ & $9(0.21)$ & & $11(0.26)$ & $31(0.78)$ & \\
\hline Positive & $3(0.25)$ & $5(0.42)$ & $4(0.33)$ & 0.681 & $3(0.25)$ & $9(0.22)$ & 0.626 \\
\hline \multicolumn{8}{|c|}{ Epithelial cells VEGFR+ } \\
\hline Negative & $11(0.39)$ & $13(0.47)$ & $4(0.14)$ & & $11(0.39)$ & $17(0.42)$ & \\
\hline Positive & $3(0.11)$ & $14(0.54)$ & $9(0.35)$ & 0.039 & $3(0.11)$ & $23(0.58)$ & 0.030 \\
\hline
\end{tabular}

${ }^{\mathrm{a}}$ Fisher exact test

VEGFR2 expression is not specific of endothelial cells; it is mainly expressed in malignant epithelium where VEGF can act as a promoter of tumor cell proliferation. The expression of VEGFR2 in epithelial prostate carcinoma cells has been rarely reported, and its role in the occurrence and development of prostate cancer remains unclear. Previous immunohistochemistry studies reported VEGFR2 expression in high-grade prostate intra-epithelial neoplasia and carcinomas of the prostate [40-42], whereas gene expression findings evidenced expression of $K D R$ mRNA in prostate cancer cell lines and a functional impact of using a KDR antisense oligonucleotide in suppressing cell proliferation and promoting apoptosis [43, 44].

The body of past evidences, taken together with present findings indicates that the distribution of VEGFR2 expression towards epithelial prostate carcinoma cells supports a function for VEGF that is not limited to angiogenesis. Thus, abrogation of VEGFR2 signalling in malignant epithelial cells may prove an effective therapeutic modality for the treatment of prostate cancer. At present, two antiangiogenic drugs are being tested in the phase III setting

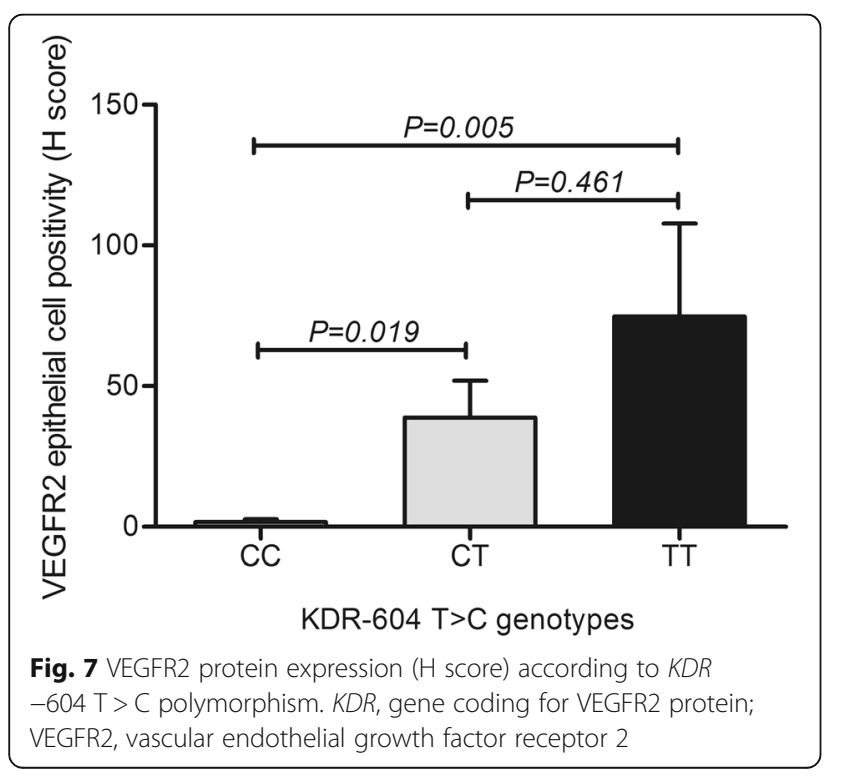

for men with prostate cancer, carbozantinib (a dual VEGFR2/MET inhibitor) and tasquinimod (down-regulator of HIF-1 $\alpha$ ), which previously showed beneficial and encouraging results on phase II trials [45].

Cancer-associated hypoxia switches cell metabolism towards increased production of acidic metabolites. However, tumor cells have to adapt to hypoxia and acidosis in order to survive. CAIX is a membrane-bound protein crucial to a wide variety of processes, including $\mathrm{pH}$ regulation in the highly metabolically active malignant cells. Expression of CAIX is associated with tumor cell hypoxia in a variety of human tumors, including urologic cancers [46-49]. Carbonic anhydrase IX gene $(C A 9)$ is a target of HIF- $1 \alpha$ that is up-regulated in response to hypoxia [50]. The expression of CAIX in prostate carcinoma has been rarely reported. CA9 mRNA expression increases reliably following hypoxia incubation of PC-3 cells [51], although no significant differences in CA9 mRNA expression were found when comparing nodular prostate hyperplasia with prostate carcinomas [7]. However, other studies reported lack of CAIX expression in primary prostate carcinoma and hypothesized that alternative pathway for maintaining $\mathrm{pH}$ balance (e.g. monocarboxylate transporters 2 and 4 ) $[26,52,53]$ may be more relevant than CAIX.

Our results disclosed increased frequency of cases with epithelial cell positivity for CAIX expressing in organ confined and extra prostatic carcinomas compared to $\mathrm{BPH}$. Despite recent concern arisen for the specificity of the CAIX polyclonal antibody generated against a C-terminal peptide in detecting CAIX (except when used at high dilution, in prostate tissues) [54], in this study we used the antibody at a dilution of 1:1000 and found membranebound staining for CAIX. Therefore, our findings are likely to reflect reliable expression of CAIX in epithelial prostate cells. Our findings taken together with reports of CAIX expression in malignant prostate epithelial cells [7, $51,55]$ sustains the need for reconsidering CAIX role in prostate carcinoma. CAIX may serve as one of the mechanisms by which prostate carcinoma cells regulate extracellular $\mathrm{pH}$ and induce cytoplasmic alkalization. 
Table 4 Expression of proteins from hypoxia pathways in prostate cancer patients, by Gleason grade and PSA value

\begin{tabular}{|c|c|c|c|c|c|c|}
\hline & \multicolumn{3}{|c|}{ Gleason grade $(n=38)$} & \multicolumn{3}{|c|}{ PSA at diagnosis $(n=36)$} \\
\hline & $<7$ & $\geq 7$ & $P$ & $\overline{<10}$ & $\geq 10$ & $P$ \\
\hline VEGFR2 H-score ${ }^{a}$ & $30.9 \pm 24.7$ & $60.1 \pm 17.9$ & 0.099 & $30.2 \pm 1.2$ & $80.0 \pm 33.5$ & 0.085 \\
\hline LOX immunoreactivity score ${ }^{a}$ & $10.2 \pm 1.6$ & $7.6 \pm 1.1$ & 0.184 & $9.2 \pm 1.1$ & $6.6 \pm 1.8$ & 0.242 \\
\hline \multicolumn{7}{|l|}{ HIF-1a expression ${ }^{b}$} \\
\hline Negative & $6(0.50)$ & $19(0.73)$ & & $17(0.65)$ & $8(0.80)$ & $0.335^{c}$ \\
\hline Positive & $6(0.50)$ & $7(0.27)$ & 0.163 & $9(0.35)$ & $2(0.20)$ & \\
\hline \multicolumn{7}{|l|}{ CAIX expression ${ }^{b}$} \\
\hline Negative & $10(0.83)$ & $15(0.58)$ & & $19(0.73)$ & $5(0.50)$ & \\
\hline Positive & $2(0.17)$ & $11(0.42)$ & $0.117^{c}$ & $7(0.27)$ & $5(0.50)$ & 0.078 \\
\hline
\end{tabular}

PSA prostate specific antigen, VEGFR2 vascular endothelial growth factor receptor 2, LOX lysyl oxidase, HIF1a hypoxia inducible factor 1 alpha, CAIX carbonic anhydrase IX

${ }^{a}$ Kruskal Wallis and Mann-Whitney $\mathrm{U}$ tests for VEGFR2 H-score in epithelial cells; ${ }^{\mathrm{b}}$ Chi-square test. ${ }^{\mathrm{c}}$ Fisher exact test

The lysyl oxidase gene $(L O X)$, one of the overexpressed genes among a tumor hypoxia signature [56, 57], was shown to be directly regulated by HIF-1 $\alpha$ transcription factor and is essential for hypoxia-induced metastasis and cancer cell proliferation [58]. Hypoxia-driven cancer cell invasion is severely impaired when LOX expression or oxidase activity were inhibited [59]. In prostate tissue we found that the LOX immunoreactivity score correlated with HIF- $1 \alpha$ expression, thus supporting the regulatory nature of HIF-1 $\alpha$ in LOX expression. Furthermore, although we have not observed an overrepresentation of cases with positive LOX expression in carcinomas compared to nodular prostate hyperplasia, the LOX immunoreactivity score was significantly higher in organ confined prostate carcinomas compared to nodular prostate hyperplasia. Interestingly, previous reports showed significantly increased expression of LOX mRNA in prostate carcinomas compared to nodular prostate hyperplasia [7], whereas stronger LOX expression was also observed in other solid malignancies [27, 60,61]. LOX is known to participate in critical biological functions that include cell migration, cell polarity, epithelial-to-mesenchymal transition (EMT) and angiogenesis [58] (reviewed in Fraga et al., 2015) [62], which fits with the increased LOX expression found in our carcinomas. Altogether, we suggest the possibility that a HIF- $1 \alpha / L O X$ regulatory mechanism may act in synergy to foster tumor formation along with the adaptation of tumor cells to hypoxia.

The analysis of protein expression in distinct pathological groups (by stage, differentiation score and PSA serum levels at diagnosis), which are predictive of prostate cancer aggressiveness, showed at most only trends for increased expression of VEGFR2 in carcinomas with Gleason $>7$ or patients with PSA $>10 \mathrm{ng} / \mathrm{mL}$, and of CAIX in patients with PSA $>10 \mathrm{ng} / \mathrm{mL}$. These findings indicate relevant clues but require further studies.

The genotypic distributions for the putative functional target SNPs in HIF1A, LOX, CA9 and KDR were similar between nodular prostate hyperplasia and prostate carcinomas. We might have hypothesized that carriers of variant alleles are prone to be more susceptible to have cancer, but the underpowered sample size limits conclusions regarding genetic association for these SNPs. Nevertheless, it is expected that only the combination of several SNPs within pathways or mechanisms may have significant impact in the association with complex diseases as prostate carcinoma. Further studies are warranted to evaluate the predictive/prognostic value of these genetic polymorphisms in prostate cancer.

In this study, evaluation of protein expression according to SNPs in the respective coding genes disclosed a genotype-phenotype effect for the LOX and $K D R$ SNPs, but no functional validation at the protein level was observed for the studied HIF1A and CA9 SNPs. In the HIF1A gene, a C-to-T substitution at locus +1772 (rs11549465) results in non-synonymous proline-by-serine aminoacid substitution at codon 582. Association studies of this SNP with prostate carcinoma risk and with microvessel density, yielded conflicting results $[13,16,19,20,63-65]$. This SNP localizes in the oxygen-dependent domain of the gene where the variant allele was shown to stabilize HIF1A mRNA and enhance HIF1A transcriptional activity [64]. In our study there were no differences in HIF$1 \alpha$ protein expression according to the HIF1A +1772 $\mathrm{C}>\mathrm{T}$ genotypes as reported previously in localised prostatic carcinomas [16]. As we measured HIF- $1 \alpha$ protein levels and it is known that HIF1A is subjected to post-transcriptional and post-translational regulation [66], this SNP may indeed influence mRNA transcription that is not reflected in protein expression. The low frequency of $\mathrm{T}$ homozygous genotype in our sample (only 2 cases carried TT genotype) may have influenced statistical power, since the HIF-1 $\alpha$ protein and mRNA overexpression have been associated with the HIF1A +1772 TT $[14,67,68]$. 
A functional genetic variant on $K D R$ gene that codifies for VEGFR2 is located in the promoter region $(-604$, rs2071559), where a T-to-C substitution occurs. Preceding in vitro luciferase assays showed that the $\mathrm{C}$-allele was associated with lower transcription activity than T-allele, whereas serum VEGFR2 levels were significantly lower in $\mathrm{CC}$ versus TT carriers [69]. Interestingly, we found that $\mathrm{CT}$ and TT carriers had significantly increased VEGFR2 expression in prostate epithelial cells. We postulate that this SNP might prove useful for predictive and/or prognostic evaluations in prostate carcinoma. Studies in colorectal cancer reported association of this SNP in KDR with susceptibility and recurrence [70,71], whereas, to the best of our knowledge, no studies using this SNP were conducted in prostate carcinoma patients. Likewise, it is expected that this SNP might increase susceptibility to prostate cancer by upregulating the number of available VEGFR2 proteins in malignant cells.

A SNP in exon 1 of $C A 9$ gene is located at locus +201 (rs2071676), where an A-to-G substitution leads to a change of valine-by-methionine in codon 33. Although we observed an overrepresentation of CAIX positive immunoreactivity in prostate carcinoma compared to $\mathrm{BPH}$, the nonsynonymous SNP in $C A 9+201$ were unable to explain variations in the levels of CAIX protein expression in the prostatic tissue. Likewise, a recent report described lack of association between the $C A 9+201$ SNP with CAIX protein expression in renal cell carcinoma [72]. These findings may suggest that lack of influence of this SNP in protein expression, even though the potential molecular structure modifications of this nonsynonymous substitution (valine to methionine) in CAIX protein activity remains to be confirmed. In fact, genetic association studies that included the $C A 9+201 \mathrm{~A}>\mathrm{G}$ polymorphism showed neither risk for renal cell carcinoma [72] nor for oral squamous cell carcinoma [73]. Noteworthy, the G-allele was associated with lymph node metastasis in oral cancer and represented increased risk for cancer when combined into a haplotype with other two SNPs in this gene [73]. Furthermore, another SNP in CA9 (rs12553173) was independently associated with improved overall survival and greater likelihood of response to therapy in renal cell carcinoma [72], thus warranting further functional analysis. In our study, although we are aware that haplotype analyses can be expedite over analysis of individual SNPs for detecting an association between alleles and a disease phenotype, the small size sample prevented the consideration of such evaluation.

The LOX gene is translated and secreted as a proenzyme (Pro-LOX), and then processed to a functional enzyme (LOX) and a propeptide (LOX-PP) [74, 75]. While LOX-PP was described as a Ras tumor suppressor, reversing mesenchymal tumor cells to a more epithelial phenotype [76-78], the LOX enzyme was found to facilitate a more migratory and invasive phenotype during breast cancer progression $[58,79]$. We studied a SNP in $L O X$ gene that has been identified at locus +473 (rs1800449), presenting a G-to-A substitution that cause an aminoacid substitution arginine-by-glutamine in codon 158. This SNP located in a highly conserved region within LOX-PP has been associated with attenuated ability of LOX-PP to oppose the effects of LOX, resulting in tumor cell invasive phenotype. Functional studies revealed that the A-allele decreases the protective capacity of LOX-PP, while increasing the Pro-LOXassociated invasive ability of tumor cells [78]. When evaluating LOX immunoreactivity and expression intensity by immunohistochemistry in prostate tissues, we found it significantly lower in carriers of the $L O X+473$ A-allele. Indeed, $L O X$ A-carriers disclosed decreased LOX protein expression in the nucleus of prostate epithelial cells.

The complex nature of LOX protein domain structure and biological functions makes noticeable that it can act as both a tumor suppressor and a metastasis promoter gene in cancer [80]. Under hypoxic conditions, the increased expression of LOX enzyme correlates with tumor invasiveness $[81,82]$. In the present study, we found that lysyl oxidase was present primarily intracellular in the nucleus of epithelial cells, which fits with other reports asserting that this enzyme may have important functions in secretory cells, either as catalyser of histones in the nucleus or in association with cytoskeletal proteins at the cytoplasm [83, 84]. Thus, our findings seem to suggest a wider variety of functions for LOX in prostate epithelial cells, beyond those related to cross-link formation in collagen and elastin, which merit further research. We hypothesize that the trafficking of LOX towards inside the cell or a specific cell compartment may be subordinated to the structural molecular characteristics and folding of the protein, which could be determined by $L O X+473 \mathrm{G}>\mathrm{A}$ polymorphism. Further studies should clarify the meaning of increased nuclear LOX intensity for PCa development.

Our endeavour to study the genotype-phenotype correlation in key hypoxia markers and its association with prostate cancer yielded novel and interesting findings, nevertheless our results should be interpreted in the context of several potential limitations. Sample size was a major issue as conclusions were impracticable for genetic association analysis and limited for genotypephenotype inferences. Nevertheless, considering the hypothesis-generating nature of this study, we report findings that provide important clues to further work in larger samples. The use of tissue microarrays for immunohistochemical evaluation has been subject of concern mainly due to limited sample of diagnostic tissue, although in our series the representative tumor sections 
were adequately selected by an experienced pathologist. The comparison of hypoxia markers between patients with benign and malignant prostate disease might attenuate differences since it is known that hypoxia is altered in cancer but also in benign hyperproliferative diseases. The group of benign prostate disease seemed adequate for several order of reasons: 1) the diagnosis was contemporary with that of cancers; 2) their advanced age at diagnosis allowed matching with elderly prostate cancer patients; 3) all patients underwent digital rectal examination, PSA testing and prostate needle biopsy, making the possibility of crossover remote, and 4) most men develop nodular prostate hyperplasia or chronic prostatitis by the 7 th-8th decades of life, making it normal in men of that age to carry benign prostatic disease.

\section{Conclusions}

Prostate carcinoma triggers an increase in hypoxia, which regulates HIF1A that in turn impacts downstream the expression of LOX, CAIX and VEGFR2 in tumor cells. In this study we observed that the inherited genetic variants in $L O X$ and $K D R$ seem to modulate the expression of LOX and VEGFR2 in carcinoma cells, supporting a genetumor microenvironment interaction in the activation of hypoxia-driven pathways in prostate carcinoma. Results presented here warrant further research in larger samples in order to evaluate the predictive and prognostic value of $K D R$ and LOX SNPs in prostate carcinoma.

\section{Additional file}

Additional file 1: Table S1. Genotypic distribution of functional SNPS in genes of hypoxia pathways by disease status using additive and recessive models analyses. The genotypic distribution of studied SNPs in genes of hypoxia pathways, using additive and recessive models, are shown according to disease status. (DOCX $17 \mathrm{~kb}$ )

\begin{abstract}
Abbreviations
95\%Cl: 95\% confidence interval; Akt: Protein kinase B; BPH: Nodular prostate hyperplasia; CA9: Carbonic anhydrase IX gene; CAIX: Carbonic anhydrase IX; EMT: Epithelial-to-mesenchymal transition; EPCa: Extra prostatic (T3-T4) Prostate Cancer; HIF-1a: Hypoxia-inducible factor 1 alpha; HIF-1 $\beta$ : Hypoxiainducible factor 1 beta; HIF1A: HIF-1a gene; IRS: Immunoreactivity score; KDR: VEGFR2 gene; LOX: Lysyl oxidase; LOX-PP: Lysyl oxidase propeptide; MAPK: Mitogen-activated protein kinase; mTOR: Mammalian target of rapamycin; OCPCa: Organ-confined (T1-T2) Prostate Cancer; OR: Odds ratio; P70S6K: Ribosomal protein S6 kinase beta-1; PCR: Polymerase chain reaction; PI3K: Phosphoinositide-3-kinase; PSA: Prostate specific antigen; SNP: Single nucleotide polymorphisms; STAT3: Signal transducer and activator of transcription 3; VEGF: Vascular endothelial growth factor; VEGFR2: Vascular endothelial growth factor receptor 2
\end{abstract}

\section{Acknowledgements}

Authors acknowledge the support of the Portuguese League Against Cancer - North Centre.

\section{Funding}

RR was supported by the Portuguese League Against Cancer - North Centre. We declare no role of the funding body in the design of the study and collection, analysis, and interpretation of data and in writing the manuscript.

\section{Availability of data and material}

"The datasets analysed during the current study are available from the corresponding author on reasonable request.", stated at the end of the Statistical analysis section.

\section{Authors' contributions}

AF: Conception and design, Acquisition of data, Drafting the manuscript; RR: Conception and design, Analysis and interpretation of data, Drafting the manuscript; AC: Acquisition of data, Drafting the manuscript; JRV: Acquisition of data, Revising the manuscript critically for important intellectual content; HC: Acquisition of data, Drafting the manuscript; JML: Analysis and interpretation of data, Revising the manuscript critically for important intellectual content; PP: Acquisition of data, Drafting the manuscript; CLobato: Acquisition of data, Revising the manuscript critically for important intellectual content; CLopes: Conception and design, Revising the manuscript critically for important intellectual content; RM: Analysis and interpretation of data, Revising the manuscript critically for important intellectual content. All authors provided final approval of the version to be published and agreed to be accountable for all aspects of the work.

\section{Competing interests}

The authors declare that they have no competing interests.

\section{Consent for publication}

Not applicable.

\section{Ethics approval and consent to participate}

"This study was conducted with informed written consent by participants and after approval by the Porto Hospital Centre Ethical Committee", stated in page 4.

\section{Author details}

1Department of Urology, Porto Hospital Centre - St. António Hospital, Largo Prof. Abel Salazar, 4000-001 Porto, Portugal. ${ }^{2}$ Center for Urological Research, Department of Urology, Porto Hospital Centre - St. António Hospital, Porto, Portugal. ${ }^{3}$ ICBAS, Abel Salazar Biomedical Sciences Institute, University of Porto, Porto, Portugal. ${ }^{4}$ Molecular Oncology Group - Cl, Portuguese Institute of Oncology, Porto, Portugal. ${ }^{5}$ Genetics Laboratory, Faculty of Medicine, University of Lisbon, Lisbon, Portugal. ${ }^{6}$ Department of Pathology, Porto Hospital Centre - St. António Hospital, Porto, Portugal. ${ }^{7}$ Department of Pathology and Oncology, Faculty of Medicine, University of Porto, Porto, Portugal. ${ }^{8}$ Institute of Pathology and Molecular Immunology of University of Porto (IPATIMUP), Porto, Portugal. ${ }^{9}$ Department of Urology, Porto Military Hospital, Porto, Portugal.

Received: 6 October 2016 Accepted: 10 January 2017

Published online: 31 January 2017

\section{References}

1. Jemal A, Bray F, Center MM, Ferlay J, Ward E, Forman D. Global cancer statistics. CA Cancer J Clin. 2011;61(2):69-90.

2. Wiklund F. Prostate cancer genomics: can we distinguish between indolent and fatal disease using genetic markers? Genome Med. 2010;2(7):45.

3. Fraga A, Ribeiro R, Medeiros R. Tumor hypoxia: the role of HIF. Actas Urol Esp. 2009;33(9):941-51.

4. Pouyssegur J, Dayan F, Mazure NM. Hypoxia signalling in cancer and approaches to enforce tumour regression. Nature. 2006;441 (7092):437-43.

5. Harris AL. Hypoxia-a key regulatory factor in tumour growth. Nat Rev Cancer. 2002;2(1):38-47.

6. Brahimi-Horn MC, Pouyssegur J. The hypoxia-inducible factor and tumor progression along the angiogenic pathway. Int Rev Cytol. 2005;242:157-213.

7. Stewart GD, Gray K, Pennington CJ, Edwards DR, Riddick AC, Ross JA, Habib FK. Analysis of hypoxia-associated gene expression in prostate cancer: lysyl oxidase and glucose transporter-1 expression correlate with Gleason score. Oncol Rep. 2008;20(6):1561-7. 
8. Gupta S, Srivastava M, Ahmad N, Bostwick DG, Mukhtar H. Over-expression of cyclooxygenase-2 in human prostate adenocarcinoma. Prostate. 2000; 42(1):73-8.

9. Baltaci S, Orhan D, Gogus C, Turkolmez K, Tulunay O, Gogus O. Inducible nitric oxide synthase expression in benign prostatic hyperplasia, low- and high-grade prostatic intraepithelial neoplasia and prostatic carcinoma. BJU Int. 2001;88(1):100-3

10. Vergis R, Corbishley CM, Norman AR, Bartlett J, Jhavar S, Borre M, Heeboll S, Horwich A, Huddart R, Khoo V, et al. Intrinsic markers of tumour hypoxia and angiogenesis in localised prostate cancer and outcome of radical treatment: a retrospective analysis of two randomised radiotherapy trials and one surgical cohort study. Lancet Oncol. 2008;9(4):342-51.

11. Teixeira AL, Ribeiro R, Morais A, Lobo F, Fraga A, Pina F, Calais-da-Silva FM, Calais-da-Silva FE, Medeiros R. Combined analysis of EGF $+61 \mathrm{G}>\mathrm{A}$ and TGFB1 + 869T > C functional polymorphisms in the time to androgen independence and prostate cancer susceptibility. Pharmacogenomics J. 2009;9(5):341-6.

12. Ribeiro RJ, Monteiro CP, Azevedo AS, Cunha VF, Ramanakumar AV, Fraga AM, Pina FM, Lopes CM, Medeiros RM, Franco EL. Performance of an adipokine pathway-based multilocus genetic risk score for prostate cancer risk prediction. PLOS ONE. 2012;7(6), e39236.

13. Fraga A, Ribeiro R, Principe P, Lobato C, Pina F, Mauricio J, Monteiro C, Sousa H, CalaisdaSilva F, Lopes $C$, et al. The HIF1A functional genetic polymorphism at locus +1772 associates with progression to metastatic prostate cancer and refractoriness to hormonal castration. Eur J Cancer. 2014;50(2):359-65.

14. Vainrib M, Golan M, Amir S, Dang DT, Dang LH, Bar-Shira A, Orr-Urtreger A, Matzkin H, Mabjeesh NJ. HIF1A C1772T polymorphism leads to HIF-1alpha mRNA overexpression in prostate cancer patients. Cancer Biol Ther. 2012; 13(9):720-6

15. Ye Y, Wang M, Hu S, Shi Y, Zhang X, Zhou Y, Zhao C, Wang G, Wen J, Zong $H$. Hypoxia-inducible factor-1alpha C1772T polymorphism and cancer risk: a meta-analysis including 18,334 subjects. Cancer Investig. 2014;32(4):126-35.

16. Foley $R$, Marignol L, Thomas AZ, Cullen IM, Perry AS, Tewari P, O'Grady A, Kay E, Dunne B, Loftus B, et al. The HIF-1alpha C1772T polymorphism may be associated with susceptibility to clinically localised prostate cancer but not with elevated expression of hypoxic biomarkers. Cancer Biol Ther. 2009;8(2):118-24.

17. Chau CH, Permenter MG, Steinberg SM, Retter AS, Dahut WL, Price DK, Figg WD. Polymorphism in the hypoxia-inducible factor 1alpha gene may confer susceptibility to androgen-independent prostate cancer. Cancer Biol Ther. 2005;4(11):1222-5.

18. Fu XS, Choi E, Bubley GJ, Balk SP. Identification of hypoxia-inducible factor-1alpha (HIF-1alpha) polymorphism as a mutation in prostate cancer that prevents normoxia-induced degradation. Prostate. 2005; 63(3):215-21.

19. Li P, Cao Q, Shao PF, Cai HZ, Zhou H, Chen JW, Qin C, Zhang ZD, Ju XB, Yin CJ. Genetic polymorphisms in HIF1A are associated with prostate cancer risk in a Chinese population. Asian J Androl. 2012;14(6):864-9.

20. Li H, Bubley GJ, Balk SP, Gaziano JM, Pollak M, Stampfer MJ, Ma J. Hypoxia-inducible factor-1alpha (HIF-1alpha) gene polymorphisms, circulating insulin-like growth factor binding protein (IGFBP)-3 levels and prostate cancer. Prostate. 2007;67(12):1354-61.

21. Ranasinghe WK, Baldwin GS, Bolton D, Shulkes A, Ischia J, Patel O. HIF1alpha expression under normoxia in prostate cancer: which pathways to target? J Urol. 2014;193:763-70.

22. Zhao T, LV J, Zhao J, Nzekebaloudou M. Hypoxia-inducible factor-1alpha gene polymorphisms and cancer risk: a meta-analysis. J Exp Clin Cancer Res. 2009;28:159.

23. Heidenreich A, Bastian PJ, Bellmunt J, Bolla M, Joniau S, van der Kwast T, Mason M, Matveev V, Wiegel T, Zattoni F, et al. EAU guidelines on prostate cancer. part 1: screening, diagnosis, and local treatment with curative intent-update 2013. Eur Urol. 2014;65(1):124-37.

24. Pertega-Gomes N, Vizcaino JR, Miranda-Goncalves V, Pinheiro C, Silva J, Pereira H, Monteiro P, Henrique RM, Reis RM, Lopes C, et al. Monocarboxylate transporter 4 (MCT4) and CD147 overexpression is associated with poor prognosis in prostate cancer. BMC Cancer. 2011;11:312.

25. Holzer TR, Fulford AD, Nedderman DM, Umberger TS, Hozak RR, Joshi A, Melemed SA, Benjamin LE, Plowman GD, Schade AE, et al. Tumor cell expression of vascular endothelial growth factor receptor 2 is an adverse prognostic factor in patients with squamous cell carcinoma of the lung. PLoS ONE. 2013;8(11), e80292.
26. Smyth LG, O'Hurley G, O'Grady A, Fitzpatrick JM, Kay E, Watson RW. Carbonic anhydrase IX expression in prostate cancer. Prostate Cancer Prostatic Dis. 2010;13(2):178-81.

27. Albinger-Hegyi A, Stoeckli SJ, Schmid S, Storz M, lotzova G, Probst-Hensch NM, Rehrauer $\mathrm{H}$, Tinguely M, Moch $\mathrm{H}$, Hegyi I. Lysyl oxidase expression is an independent marker of prognosis and a predictor of lymph node metastasis in oral and oropharyngeal squamous cell carcinoma (OSCC). Int J Cancer J International du cancer. 2010;126(11):2653-62

28. Semenza GL. Hypoxia-inducible factors in physiology and medicine. Cell. 2012:148(3):399-408.

29. Zhong H, Agani F, Baccala AA, Laughner E, Rioseco-Camacho N, Isaacs WB, Simons JW, Semenza GL. Increased expression of hypoxia inducible factor-1alpha in rat and human prostate cancer. Cancer Res. 1998; 58(23):5280-4.

30. Zhong H, De Marzo AM, Laughner E, Lim M, Hilton DA, Zagzag D, Buechler P, Isaacs WB, Semenza GL, Simons JW. Overexpression of hypoxia-inducible factor 1alpha in common human cancers and their metastases. Cancer Res. 1999; 59(22):5830-5

31. Saramaki OR, Savinainen KJ, Nupponen NN, Bratt O, Visakorpi T. Amplification of hypoxia-inducible factor 1alpha gene in prostate cancer. Cancer Genet Cytogenet. 2001;128(1):31-4.

32. Ranasinghe WK, Xiao L, Kovac S, Chang M, Michiels C, Bolton D, Shulkes A, Baldwin GS, Patel O. The role of hypoxia-inducible factor 1alpha in determining the properties of castrate-resistant prostate cancers. PLoS ONE. 2013;8(1), e54251.

33. Bos R, Zhong H, Hanrahan CF, Mommers EC, Semenza GL, Pinedo HM, Abeloff MD, Simons JW, Van Diest PJ, van der Wall E. Levels of hypoxiainducible factor-1 alpha during breast carcinogenesis. J Natl Cancer Inst. 2001;93(4):309-14.

34. Birner $P$, Schindl M, Obermair A, Breitenecker G, Oberhuber G Expression of hypoxia-inducible factor 1alpha in epithelial ovarian tumors: its impact on prognosis and on response to chemotherapy. Clin Cancer Res. 2001;7(6):1661-8.

35. Aebersold DM, Burri P, Beer KT, Laissue J, Djonov V, Greiner RH, Semenza GL. Expression of hypoxia-inducible factor-1alpha: a novel predictive and prognostic parameter in the radiotherapy of oropharyngeal cancer. Cancer Res. 2001;61(7):2911-6

36. Waldner MJ, Wirtz S, Jefremow A, Warntjen M, Neufert C, Atreya R, Becker C, Weigmann B, Vieth M, Rose-John S, et al. VEGF receptor signaling links inflammation and tumorigenesis in colitis-associated cancer. J Exp Med. 2010;207(13):2855-68

37. Kroll J, Waltenberger J. The vascular endothelial growth factor receptor KDR activates multiple signal transduction pathways in porcine aortic endothelial cells. J Biol Chem. 1997;272(51):32521-7.

38. Gerber HP, McMurtrey A, Kowalski J, Yan M, Keyt BA, Dixit V, Ferrara N. Vascular endothelial growth factor regulates endothelial cell survival through the phosphatidylinositol 3'-kinase/Akt signal transduction pathway. Requirement for Flk-1/KDR activation. J Biol Chem. 1998;273(46):30336-43.

39. Saraswati S, Kumar S, Alhaider AA. alpha-santalol inhibits the angiogenesis and growth of human prostate tumor growth by targeting vascular endothelial growth factor receptor 2-mediated AKT/mTOR/P70S6K signaling pathway. Mol Cancer. 2013;12:147.

40. Hahn D, Simak R, Steiner GE, Handisurya A, Susani M, Marberger M. Expression of the VEGF-receptor Flt-1 in benign, premalignant and malignant prostate tissues. J Urol. 2000;164(2):506-10.

41. Ferrer FA, Miller LJ, Lindquist R, Kowalczyk P, Laudone VP, Albertsen PC, Kreutzer DL. Expression of vascular endothelial growth factor receptors in human prostate cancer. Urology. 1999;54(3):567-72.

42. Pallares J, Rojo F, Iriarte J, Morote J, Armadans LI, De Torres I. Study of microvessel density and the expression of the angiogenic factors VEGF, bFGF and the receptors Flt- 1 and FLK-1 in benign, premalignant and malignant prostate tissues. Histol Histopathol. 2006;21(8):857-65.

43. Bai AS, Zeng $H$, Li X, Wei Q, Li H, Yang YR. Expression of kinase insert domain-containing receptor in prostate adenocarcinoma. Zhonghua nan ke xue = National journal of andrology. 2007;13(4):324-6.

44. Song J, Song Y, Guo W, Jia J, Jin Y, Bai A. Regulatory roles of KDR antisense oligonucleotide on the proliferation of human prostate cancer cell line PC3. J BUON. 2014:19(3):770-4.

45. Schweizer MT, Carducci MA. From bevacizumab to tasquinimod: angiogenesis as a therapeutic target in prostate cancer. Cancer J. 2013. 19(1):99-106 
46. Sherwood BT, Colquhoun AJ, Richardson D, Bowman KJ, O'Byrne KJ, Kockelbergh RC, Symonds RP, Mellon JK, Jones GD. Carbonic anhydrase IX expression and outcome after radiotherapy for muscle-invasive bladder cancer. Clin Oncol. 2007;19(10):777-83.

47. Swinson DE, Jones JL, Richardson D, Wykoff C, Turley H, Pastorek J, Taub N, Harris AL, O'Byrne KJ. Carbonic anhydrase IX expression, a novel surrogate marker of tumor hypoxia, is associated with a poor prognosis in non-smallcell lung cancer. J Clin Oncol. 2003;21(3):473-82.

48. Bui MH, Seligson D, Han KR, Pantuck AJ, Dorey FJ, Huang Y, Horvath S, Leibovich BC, Chopra S, Liao SY, et al. Carbonic anhydrase IX is an independent predictor of survival in advanced renal clear cell carcinoma: implications for prognosis and therapy. Clin Cancer Res. 2003;9(2):802-11.

49. Ord JJ, Agrawal S, Thamboo TP, Roberts I, Campo L, Turley H, Han C, Fawcett DW, Kulkarni RP, Cranston D, et al. An investigation into the prognostic significance of necrosis and hypoxia in high grade and invasive bladder cancer. J Urol. 2007;178(2):677-82.

50. Wykoff CC, Beasley NJ, Watson PH, Turner KJ, Pastorek J, Sibtain A, Wilson GD, Turley H, Talks KL, Maxwell PH, et al. Hypoxia-inducible expression of tumor-associated carbonic anhydrases. Cancer Res. 2000;60(24):7075-83.

51. Stewart GD, Nanda J, Brown DJ, Riddick AC, Ross JA, Habib FK. NO-sulindac inhibits the hypoxia response of PC-3 prostate cancer cells via the Akt signalling pathway. Int J Cancer J International du cancer. 2009;124(1):223-32.

52. Pertega-Gomes N, Vizcaino JR, Attig J, Jurmeister S, Lopes C, Baltazar F. A lactate shuttle system between tumour and stromal cells is associated with poor prognosis in prostate cancer. BMC Cancer. 2014;14:352.

53. Pertega-Gomes N, Vizcaino JR, Gouveia C, Jeronimo C, Henrique RM, Lopes C, Baltazar F. Monocarboxylate transporter 2 (MCT2) as putative biomarker in prostate cancer. Prostate. 2013;73(7):763-9.

54. Li Y, Wang H, Oosterwijk E, Selman Y, Mira JC, Medrano T, Shiverick KT, Frost SC. Antibody-specific detection of CAIX in breast and prostate cancers. Biochem Biophys Res Commun. 2009;386(3):488-92.

55. Weber DC, Tille JC, Combescure C, Egger JF, Laouiti M, Hammad K, Granger P, Rubbia-Brandt L, Miralbell R. The prognostic value of expression of HIF1alpha, EGFR and VEGF-A, in localized prostate cancer for intermediate- and high-risk patients treated with radiation therapy with or without androgen deprivation therapy. Radiat Oncol. 2012;7:66.

56. Denko NC, Fontana LA, Hudson KM, Sutphin PD, Raychaudhuri S, Altman R, Giaccia AJ. Investigating hypoxic tumor physiology through gene expression patterns. Oncogene. 2003;22(37):5907-14.

57. Chi JT, Wang Z, Nuyten DS, Rodriguez EH, Schaner ME, Salim A, Wang Y, Kristensen GB, Helland A, Borresen-Dale AL, et al. Gene expression programs in response to hypoxia: cell type specificity and prognostic significance in human cancers. PLoS Med. 2006;3(3), e47.

58. Erler JT, Bennewith KL, Nicolau M, Dornhofer N, Kong C, Le QT, Chi JT, Jeffrey SS, Giaccia AJ. Lysyl oxidase is essential for hypoxia-induced metastasis. Nature. 2006;440(7088):1222-6.

59. Kirschmann DA, Seftor EA, Fong SF, Nieva DR, Sullivan CM, Edwards EM, Sommer P, Csiszar K, Hendrix MJ. A molecular role for lysyl oxidase in breast cancer invasion. Cancer Res. 2002;62(15):4478-83.

60. Peyrol S, Raccurt M, Gerard F, Gleyzal C, Grimaud JA, Sommer P. Lysyl oxidase gene expression in the stromal reaction to in situ and invasive ductal breast carcinoma. Am J Pathol. 1997;150(2):497-507.

61. Trivedy C, Warnakulasuriya KA, Hazarey VK, Tavassoli M, Sommer P, Johnson NW. The upregulation of lysyl oxidase in oral submucous fibrosis and squamous cell carcinoma. J Oral Pathol Med. 1999;28(6): 246-51.

62. Ribeiro R, Monteiro C, Cunha V, Oliveira MJ, Freitas M, Fraga A, Principe P, Lobato C, Lobo F, Morais A, et al. Human periprostatic adipose tissue promotes prostate cancer aggressiveness in vitro. J Exp Clin Cancer Res. 2012;31:32.

63. Orr-Urtreger A, Bar-Shira A, Matzkin H, Mabjeesh NJ. The homozygous P582S mutation in the oxygen-dependent degradation domain of HIF-1 alpha is associated with increased risk for prostate cancer. Prostate. 2007;67(1):8-13.

64. Tanimoto K, Yoshiga K, Eguchi H, Kaneyasu M, Ukon K, Kumazaki T, Oue N, Yasui W, Imai K, Nakachi K, et al. Hypoxia-inducible factor-1alpha polymorphisms associated with enhanced transactivation capacity, implying clinical significance. Carcinogenesis. 2003;24(11):1779-83.

65. Fransen $K$, Fenech $M$, Fredrikson M, Dabrosin C, Soderkvist $P$. Association between ulcerative growth and hypoxia inducible factor1alpha polymorphisms in colorectal cancer patients. Mol Carcinog. 2006; 45(11):833-40.
66. Kallio PJ, Pongratz I, Gradin K, McGuire J, Poellinger L. Activation of hypoxiainducible factor 1alpha: posttranscriptional regulation and conformational change by recruitment of the Arnt transcription factor. Proc Natl Acad Sci U S A. 1997;94(11):5667-72.

67. Wu F, Zhang J, Liu Y, Zheng Y, Hu N. HIF1alpha genetic variants and protein expressions determine the response to platinum based chemotherapy and clinical outcome in patients with advanced NSCLC. Cell Physiol Biochem. 2013;32(6):1566-76.

68. Kim HO, Jo YH, Lee J, Lee SS, Yoon KS. The C1772T genetic polymorphism in human HIF-1alpha gene associates with expression of HIF-1alpha protein in breast cancer. Oncol Rep. 2008;20(5):1181-7.

69. Wang Y, Zheng Y, Zhang W, Yu H, Lou K, Zhang Y, Qin Q, Zhao B, Yang Y, Hui R. Polymorphisms of KDR gene are associated with coronary heart disease. J Am Coll Cardiol. 2007;50(8):760-7.

70. Jang MJ, Jeon YJ, Kim JW, Cho YK, Lee SK, Hwang SG, Oh D, Kim NK. Association of VEGF and KDR single nucleotide polymorphisms with colorectal cancer susceptibility in Koreans. Mol Carcinog. 2013;52 Suppl 1:E60-69.

71. Dong G, Guo X, Fu X, Wan S, Zhou F, Myers RE, Bao G, Burkart A, Yang H, Xing J. Potentially functional genetic variants in KDR gene as prognostic markers in patients with resected colorectal cancer. Cancer Sci. 2012; 103(3):561-8.

72. De Martino M, Klatte T, Seligson DB, LaRochelle J, Shuch B, Caliliw R, Li Z, Kabbinavar FF, Pantuck AJ, Belldegrun AS. CA9 gene: single nucleotide polymorphism predicts metastatic renal cell carcinoma prognosis. J Urol. 2009;182(2):728-34.

73. Chien MH, Yang JS, Chu YH, Lin CH, Wei LH, Yang SF, Lin CW. Impacts of CA9 gene polymorphisms and environmental factors on oral-cancer susceptibility and clinicopathologic characteristics in Taiwan. PLoS ONE. 2012;7(12), e51051.

74. Trackman PC, Bedell-Hogan D, Tang J, Kagan HM. Post-translational glycosylation and proteolytic processing of a lysyl oxidase precursor. J Biol Chem. 1992;267(12):8666-71.

75. Uzel MI, Scott IC, Babakhanlou-Chase H, Palamakumbura AH, Pappano WN, Hong HH, Greenspan DS, Trackman PC. Multiple bone morphogenetic protein 1-related mammalian metalloproteinases process pro-lysyl oxidase at the correct physiological site and control lysyl oxidase activation in mouse embryo fibroblast cultures. J Biol Chem. 2001;276(25):22537-43.

76. Min C, Kirsch KH, Zhao Y, Jeay S, Palamakumbura AH, Trackman PC, Sonenshein GE. The tumor suppressor activity of the lysyl oxidase propeptide reverses the invasive phenotype of Her-2/neu-driven breast cancer. Cancer Res. 2007;67(3):1105-12.

77. Jeay S, Pianetti S, Kagan HM, Sonenshein GE. Lysyl oxidase inhibits rasmediated transformation by preventing activation of NF-kappa B. Mol Cell Biol. 2003;23(7):2251-63.

78. Min C, Yu Z, Kirsch KH, Zhao Y, Vora SR, Trackman PC, Spicer DB, Rosenberg L, Palmer JR, Sonenshein GE. A loss-of-function polymorphism in the propeptide domain of the LOX gene and breast cancer. Cancer Res. 2009;69(16):6685-93.

79. Payne SL, Fogelgren B, Hess AR, Seftor EA, Wiley EL, Fong SF, Csiszar K, Hendrix MJ, Kirschmann DA. Lysyl oxidase regulates breast cancer cell migration and adhesion through a hydrogen peroxide-mediated mechanism. Cancer Res. 2005;65(24):11429-36.

80. Payne SL, Hendrix MJ, Kirschmann DA. Paradoxical roles for lysyl oxidases in cancer-a prospect. J Cell Biochem. 2007;101(6):1338-54.

81. Erler JT, Bennewith KL, Cox TR, Lang G, Bird D, Koong A, Le QT, Giaccia AJ. Hypoxia-induced lysyl oxidase is a critical mediator of bone marrow cell recruitment to form the premetastatic niche. Cancer Cell. 2009;15(1):35-44.

82. Erler JT, Weaver VM. Three-dimensional context regulation of metastasis. Clin Exp Metastasis. 2009;26(1):35-49.

83. Kobayashi H, Ishii M, Chanoki M, Yashiro N, Fushida H, Fukai K, Kono T, Hamada T, Wakasaki H, Ooshima A. Immunohistochemical localization of lysyl oxidase in normal human skin. Br J Dermatol. 1994;131(3):325-30.

84. Wakasaki H, Ooshima A. Immunohistochemical localization of lysyl oxidase with monoclonal antibodies. Lab Investig. 1990;63(3):377-84. 